\title{
Communalization and Distribution of Pekulen Land use
}

\author{
Widhiana Hestining Puri
}

\begin{abstract}
The purpose of this study is to describe the tradition of communalization of pekulen land and the distribution of its use. This research conducted with an empirical legal research that locations in Pituruh Subdistrict, Purworejo Regency, Central Java with socio-legal approach. This research found that the communal mechanism for pekulen land was first developed by the Dutch colonial government by utilizing local customary law in order to guarantee the availability of labor and agricultural land for land taxes and cultuurstelsel. This model now transformed and has many benefits such distribute the right of land use, protecting the rights of landholders, guaranteeing the protection of land functions, maintaining the integrity of village communities, and so on. The implementation of communalization of pekulen land and distribution of its use is a mechanism of local wisdom that grows and develops by transforming the values of customary law in land regulation. This activity consists of 2 (two) things, the first is the communalization of pekulen land which carried out by taking part of the rights to work on pekulen land to be used in the control and arrangement with the hamlet/ village community. Second, the distribution of the use of pekulen land is an action to distribute the right to cultivate pekulen land. Pekulen land is a form of land rights originating from customary law which is owned by the village community who are given the right of use to members of the village community to be used for their personal interests. This paper provide new way to understanding the practice of communalization of land that initiated by the citizens. Discussion about the communal land during this only related to the tribal society or indigineus people. In fact Indonesian community, especially village in Java have communal religious character and the strong value customary law.
\end{abstract}

Index Terms: pekulen land, communal, customary law, agrarian

\section{INTRODUCTION}

Politics and law are the two sides of a coherent currency. On the one hand politics as the direction of state policy of creating law as policy instrument to carry it out. But on the other hand, the existing legal provisions will also determine the political direction of the country. So close political and legal relationships often become blades and spearheads in order to achieve the goals of the state. It can be found also in the field of agrarian. As a follow-up to the realization of state politics, a series of policies are implemented both in the form of beschiking and regelling.

Indonesia's long journey with many ups and downs once gave valuable experience how the impact of existing political choices affect the welfare and agrarian life of the community, especially in the countryside. The policy of land communalization was once the strategy of the colonial government both Dutch and British in the framework of land politics (land rent) and cultuurstelsel (forced land) aimed at exploiting the natural wealth in Indonesian. The pros and cons of political choices and state policies that are considered incompatible with the ideals of society, will give rise to resistance either in the form of open movement or a series of massive and collective steps in order to counter attack over injustice

Community resistance, especially farmers in the face of unfavorable political and social changes, is very diverse. Resistance often leads to agrarian conflicts with complex root causes. Agrarian conflict is a social phenomenon in which an interaction process exists between two (or more) people or groups who fight for the interests of the same object, ie land and objects related to the land such as water, plants, mines, and also the air that is on the land concerned ${ }^{1}$. George Junus Aditjondro distinguishes land conflicts in two categories, first of which are restorative in nature where actors from the peasants try to reclaim lost land rights and natural resource rights, such as property rights, land rights and others. Both transformative land conflicts, in which the main actors involved in the conflict are fighting for rights that they did not already have. For example, the right to own land, the right to work on the land, and so forth ${ }^{2}$. This peasant resistance movement is a form of popular politics aimed at addition to acquiring power over agrarian resources (land) also towards social change.

Learning on a transformative pattern of peasant resistance is very rare. One interesting example comes from Ngandagan and surrounding villages in Purworejo District, Central Java Province. In the past, the village's communal lands (pekulen land) were broken up in each cubic unit of 300 ubin $(1$ ubin $=14 \mathrm{~m} 2)$ and worked by kuli baku ${ }^{3}$. Every kuli baku, given the right to work on one or more culinary units depends on the contribution that can be given to the village. The weakening of communal land system causes the kulian land/ pekulen owned individually and hereditary by kuli baku. At the initiative of the village chief of observation of the tradition of land communalization and the approval of the village meeting, 90 ubin were taken to be landed communities to be managed alternately / rotating. The entire area of pekulen land has been equipped with a certificate or Letter $\mathrm{C}$ and encumbered with Land and Building Tax (PBB) which is borne by kuli baku although some of it is cultivated by cultivators/ laborer/ buruh. This policy of land communications and the distribution of its utilization on the one hand gets the support of the tenants as it is considered to be the source of the welfare of the community, but on the other hand it is threatened for its survival due to the desire 
of the landowners to take back their land. The formal legal arrangements have not paid attention to the community initiated land communal model and the distribution of land rights. In addition to the pekulen land whose ownership history is unclear, potentially become communal land/ village-owned land. Various conditions as a form of local policy in villages in Pituruh Sub-district resulted in harmonization and usefulness for the community's integrity but also a potential threat to both its existence and its potential deviation by certain parties.

The policy of communalization of pekulen land is a form of adat law norms in order to provide welfare distribution to the community and ensure the availability of manpower for rural development. Law No. 51960 about regulation of the basic principles of agrarian (UUPA) in real terms provides an illustration of the regulation of pekulen lands as land derived from adat law, land use with social functions, and its natural development that leads to individualization. Local policy becomes a unique and real learning model implemented in Java Island which is prone to agrarian conflicts. Therefore, it is very important to know how the regulation and implementation of policies at the research location can be implemented more ideally.

\section{LITERATURE REVIEW}

\section{A. History and Regulation of Pekulen Land in Indonesia}

The term pekulen comes from the word kulen or kuli. The term kuli in the region of Bagelen (Purworejo) is the same as gogol or sikep ie the party who is given authority over the communal land ${ }^{4}$. Pekulen land is a type of customary land that has communal character inherent in village authority ${ }^{5}$. According to Onghokham, the term sikep farmer in the sense that villagers with the right to land have disappeared from the village environment and replaced the word coolie (from the word coolie), namely the term British India which means workers without skills ${ }^{6}$. Pekulen land is a communal land belonging to the village which is given to the villagers. Land with the right to use for payment of this tax in Central and East Java is called gogolan, pekulen, narawita, as for its obligations in the form of natural taxes of agricultural products and labor. Gogol / sikep / kuli in the village is a group of community members who carry out the task of 'gawe desa' (social tasks in village government). These tasks include village meetings, night watches (ronda), mutual assistance, fire management, floods, and natural disasters and other forms of participation ${ }^{7}$. These gogol/ sikep/ kuli who have primary obligations to the village, although in reality they can be handed over to the tenants / laborers.

\section{B. The Communalization Policy of Pekulen Land}

The communal term in the history of the land of Indonesian society has existed long ago. Communal is derived from the word commune which means where a group of people to stay and live together where they work together and divide the work is average ${ }^{8}$. On this basis,

communal lands must satisfy elements such as (1) the land is in a group bond, (2) there is the willingness of its citizens to stay and live together, (3) there is a pattern of cultivating the land together, and (4) used for common welfare. Communal property can be part of communal land in the village or dukuh or hamlet as part of the village.

The communalization policy of pekulen land in villages in Pituruh Sub-district of Purworejo was the policy of the village government by transforming the land communalization policy that developed during the Dutch colonial period. Policies that introduce the deep-rooted tradition of this society are carried out by taking part of the authority of cultivating pekulen lands that meet a certain size to be then distributed to other economically disadvantaged farmers with rotating systems. The rotating system is aimed at equal distribution of welfare considering the amount of pekulen land affected by this policy is still limited. The period of cultivation of pekulen land rotate or by local people called buruhan land is until the cultivators died, after this the land will return to the land owner to be redistributed to other farmers. Communalization of pekulen land can take the form of 2 (two) things, namely the communalization of land use rights to work on part of the pekulen land and communalization of part of the pekulen land ownership rights. The first form is the most common in which the landowner surrenders the rights to work on some of the land to another party. The second form is a village effort in order to maintain this policy while on the one hand the history of land ownership is unclear. So that on the initiative of the village, the pekulen lands of rotated / buruhan lands that had been worked on by the laborers were placed in direct control and village arrangement. Communalization and distribution of authority over rights are carried out with awareness of landowners and regulation and supervision by village government. The overall objective of this policy is to ensure the availability of manpower for rural development and maintenance, especially agricultural infrastructure while providing welfare for the villagers.

\section{METHODOLOGY/ MATERIALS}

This research was conducted using an empirical legal research model conducted at the study sites in villages in Pituruh Subdistrict, Purworejo Regency, Central Java Province. The socio-legal approach is used to help researchers understand the various social phenomena that exist and develop in society by combining them with various formulations of positive state laws. This is important because there are many different models of regulation in the community that are still not accommodated in state law. Legal pluralism provides insight and the ability for the State to be more responsive and progressive to the various demands of the community's needs.

\section{RESULT AND FINDINGS}


Land issues, especially lands based on adat law, is closely related to village institutions as the smallest government unit in the decentralized system as provided $r$ in Law Number 6 of 2014 concerning Villages. The village in ancient times was a form of indigenous people described as a single or homogeneous legal society. The village is headed by a village head called jaro (Banten), lurah, kuwu, bekel, or high officials (Central Java and East Java) and klian (Bali) ${ }^{9}$. Recognition of the existence of village institutions as the authority in charge of regulating the existence of customary land in strong villages. Subekti mentions of the Supreme Court's jurisprudence regarding adat law, especially in relation to the village authority in the control of land through gogolan and pekulen rights ${ }^{10}$, including: first, the Supreme Court (MA) dated 21-6-1958 No. 149 K / Sip / 1958 which ruled that the District Court had no power to revise or cancel the village decision on the pekulen lands, both of M.A. Date 10-10-1956 32 K / Sip / 1956 which according to customary law in Sukorejo Village, Lamongan Regency, gogol land (not yasan land) can only be abused or borrowed by people who live in the village area. It is in harmony with the nature of the rights of gogolan as a right that comes from the village adat rights. The right can only be granted to members of the village community itself and not to "outsiders". The three decisions of M.A. dated 18-101958301 K / Sip / 1958 that the appointment of pekulen land is the sole right of the village meeting, granted by adat law. The District Court is not entitled to review the decision of the village meeting. The decision of a village meeting can be seen as the implementation of the village tenure rights (doorpsbeschikkingsrecht), from the time honored by the court, in a sense not to be judged anymore.

The concept of adat law that develops in traditional villages describes the main features of togetherness and mutual cooperation, magical-religious, concrete (attention to the number and repetition of concrete relationships), and visual (established with visible bonds). The characteristics of adat law communities can be categorized in 2 (two) terms, in the outer islands based on genealogical / hereditary factors while the Javanese community is based on territorial / territorial factors ${ }^{11}$. This means that the bonds that arise from the community group is different so that it also affects the communal character.

Communalization policy in rural communities can be categorized as public policy. Public policy according to Thomas R. Dye is whatever the government chooses to do and not $\mathrm{do}^{12}$. The communalization policy was chosen to be the instrument of local village government in realizing the common welfare of the community and the progress of rural development. The mechanism of land communalization according to Slamet Muljana is a certain mechanism for even distribution of land in the village community even before the colonial period ${ }^{13}$. According to van Vollenhoven this is a form of repartitional communes that strengthen abnormally the ulayat right of the village. The pekulen lands that are subject to this policy are initially pekulen lands that meet the size of 1 (one) kuli where for each village has a different area. Of the 49 (forty-nine) villages in the Pituruh Subdistrict, there are 26 villages or around $53 \%$ of villages implementing this policy. Table 1 shows the standards of lands in the policy of pekulen land communalization and distribution of utilization in villages in pituruh sub-district.

\begin{tabular}{|c|c|c|c|c|c|}
\hline \multirow[t]{2}{*}{$\mathrm{S}_{0}$} & \multirow[t]{2}{*}{ Filage Vant } & \multicolumn{2}{|c|}{$\begin{array}{l}1 \text { Koli Fur (Permanent) } \\
\text { Petulea Land }\end{array}$} & \multicolumn{2}{|c|}{$\begin{array}{l}\text { (Rotating) Pebulea Land } \\
\text { Burthan }\end{array}$} \\
\hline & & in uhins & in maten & in utins & in neters \\
\hline 1 & Monotuse & 301 & 4210 & 50 & 760 \\
\hline : & Tavikusdte & 501 & 7010 & 101 & 1401 \\
\hline 3 & Tapen & 501 & 7010 & 125 & 1751 \\
\hline 4 & Tersiä biłt & 509 & 11200 & 29 & 2501 \\
\hline 5 & Tensiä Lor & 509 & 11200 & 301 & 4201 \\
\hline 6 & Seksirtio & 209 & 2810 & 80 & 1121 \\
\hline 7 & Pepe & 39 & 4210 & 10 & 1401 \\
\hline 8 & Balinati & 409 & 5610 & 105 & 1401 \\
\hline 9 & Kendalreje & 369 & 5040 & 60 & 840 \\
\hline 18 & Ngmpel & 361 & 5040 & 60 & 840 \\
\hline II & Siknmbay & 361 & 5040 & 60 & 840 \\
\hline 12 & Injugtejo & 321 & 4450 & 108 & 1401 \\
\hline 13 & Disen wetan & (5) & 1540 & 198 & $1+0 \mathrm{~s}$ \\
\hline 14 & Disen Kulon & 509 & 7010 & 60 & 840 \\
\hline 15 & Blekink & 409 & 5610 & 101 & $1+01$ \\
\hline 16 & Tan & 409 & 5610 & 50 & 700 \\
\hline 17 & Penguma & +6 & 561 & 8 & 112 \\
\hline 18 & Samberg & 169 & 2240 & 20 & 260 \\
\hline 19 & Megulng Kidil & 201 & 2810 & 80 & 1121 \\
\hline 70 & Pithruh & 421 & $\$ 990$ & 121 & 1681 \\
\hline 21 & Prigela & 33 & 4620 & 60 & 840 \\
\hline HI & Manganyar & 34 & 4760 & 90 & 1261 \\
\hline 23 & Megulung Lir & 309 & 4210 & 101 & $1+01$ \\
\hline 24 & Prapag bidd & 301 & 4210 & 35 & 490 \\
\hline 15 & B̈mbanghaning & 10 & 1410 & 15 & 350 \\
\hline 26 & Jgnahgan & 301 & 1210 & 45 & 630 \\
\hline
\end{tabular}

Table1 The Standards of Lands size in the Policy of Communalization and Distribution of Pekulen Land Use In Villages In Pituruh Sub-district

Source: Primary Data, 2017.

The size of 1 (one) kuli is the size used since ancient times and applies in each village. The size of the land used is ubin, where 1 (one) ubin is equal to $14 \mathrm{~m} 2$. At the time the area of lands is still abundant and the number of people is still small make the allocation of communal lands and distribution of utilization able to provide welfare for the wider community. As for recipients of rotating land / buruhan land are tuna kisma or gurem farmer which is economically less prosperous in terms of general assessment of the local community.

In general, lands/ land located in flat areas in Pituruh Subdistrict are called kuli lands/ pekulen and is composed of the parts that are called bonggol/ kuli, buruhan/ buruan/ sanggan gawe, and pucukan/ buntutan. Bonggol/ kuli is part of the pekulen land which has the most area compared to other parts cultivated by the owner. Sawah buruhan/ buruan/ sanggan gawe are part of the kuli/ pekulen land which ar 
handed over to the village/ cultivators as a reward/ wage for agricultural labor. Pucukan/ buntutan is the smallest part of the pekulen land and is usually used as a place to sow rice seeds. Pucukan/ buntutan covers only 3-10 ubin and is managed by kuli. The figure 1 shows the pekulen land component.

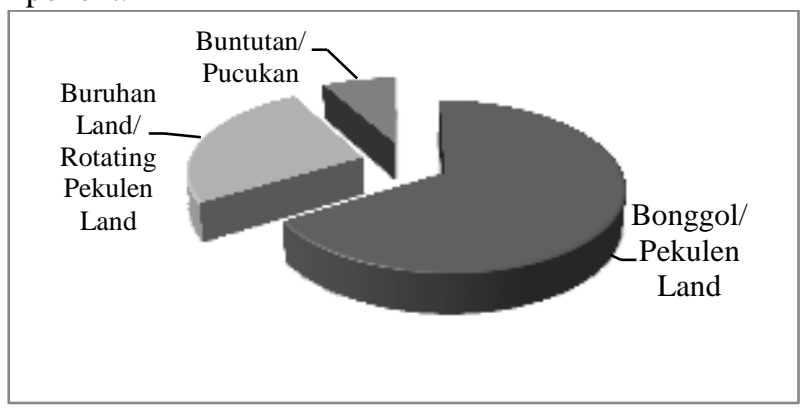

Figure 1 The Component Of Pekulen Land

The purpose of the claim is over buruhan land/ sanggan gawe in order to bind labor while providing protection during the period of Dutch colonialism. The laborers are obliged to assist all the work of cultivating the owner's fields to achieve results of agricultural productivity that have been targeted by the Dutch. In addition, it is also obligatory to assist all the troubles of the owners of lands outside of agriculture such as building houses, repairing tiles, cleaning the garden, and other work. At present, the obligations of the workers / laborers include, first working on rotating pekulen land/ active buruhan land, secondly carrying out community work/ kerigan to replace kuli according to village needs in the form of maintenance of water lines/ irrigation/ oloran and village roads, thirdly carrying out night patrols/ ronda to ensure security and order in the village environment, fourth to pay contributions in order to support the progress of the village, fifth provide and carry out various salvation held by the village, for example the celebration of 1 muharram / suronan, the sixth provide the energy needed for various social activities in the village such as people who die / sripah and hajatan and others. Arrangements regarding the communalization and distribution of pekulen land have restrictions on certain territorial areas. This means that the existing pekulen lands in a hamlet will only be communalization/ partially taken to subsequently be distributed to the community where the pekulen land are located. If the location between bonggol and the buruhan lands are separated, then the location of the pekulen land is the reference location for the cultivator.

In the past, the removal of pekulen land could not be carried out. The owner and the cultivator only have the authority to work with the village. After strengthening the pekulen rights which are increasingly individualized, buying and selling of land can be done, namely that it can only be done on the part of the bonggol/ kuli which will automatically include the buruhan land. If the buyer does not accept the buruhan land because the sale of pekulen land without buruhan, this is called the kuli gundul land. Usually the buyer will question the buruhan land as a form of the landowner's contribution to the village's progress.

The mechanism is valid for each shift in the lands to remain good through buying and selling, inheritance, and so on. Both of mechanisms are the efforts of the village government to maintain and guarantee the availability of rotating pekulen land/ buruhan land.

The regulation of buruhan land policy or reductions sawah kuli/ pekulen is an agreement of all villagers in order to preserve traditional traditions and laws in the past. For people who do not want to implement this provision, they will be subject to social sanctions. Sanctions can be in the form of a ban on buying and selling pekulen land, cutting/ taking buruhan land persuasively by the village, as well as other social sanctions such as being subject to other community gossip. Sanctions can also be given to the cultivators who do not carry out the obligations of the village, starting from reprimand to the revocation of the right to cultivate the rotating pekulen land/ buruhan land.

Village deliberation/ rembug desa is a mechanism for the community to solve village problems and make joint decisions. The implementation of the village meeting/ deliberation was led by the village head and involved all elements of the community, both village officials, community leaders, religious leaders, and all members of the community. Village meetings/ village deliberation in Pituruh sub-district are called pologoro. Pologoro is held every time is a village head election (at this time every 6 years) but it is possible to be held every year if there are urgent problems that must be discussed and resolved. Pologoro carried out at the village hall and discuss issues related to social and community matters such as the implementation of the village sanggan gawe, division of bengkok land for apparatus, wages of farm laborers, requirements of candidates for village heads, and so forth. Results pologoro is a decision about a problem agreed upon by all people. The agreement is effective and implemented by the community even though the form can be written and not written

Communal meaning in community ties shown by villagers is an illustration of human belief in its role and function in the world. Society realizes that as a human being has 2 (two) roles, namely as a personal being and as a social being. In his position as a personal being, man has a series of obligations and rights as well as authority in carrying out functions for his own sake. This function is related to its existence to survive through fulfilling needs and developing itself. The position of humans as social beings is the human point of view when dealing with other humans. Humans are expected to be able to maintain harmony with other human beings so that they can form a common life in a community. Equality of purpose becomes an important factor that forms the basis of togetherness in addition to other factors related to personal and community character such as similarity in ethnicity, religion, race, kinship, and similarity in territorial territory.

The development which was marked by a shift in the purpose of land communalization was influenced by the development of national politics. The birth of this policy as a form of exploitation in the future landrent and cultuurstelsel, the aim is to achieve high productivity in

Published By: 
agriculture. After independence, the colonial government's exploitation of crops and taxes in the villages has disappeared, leaving a policy of rice land communalization aimed at encouraging the welfare of the communityThe social function of the land is inherent and internalized by the community in the cultivation of pekulen lands so that even though they are owned individually but still provide distribution opportunities for utilization to other farmers in need. The New Order period with the principle of developmentism encourages agriculture to be a sector that must achieve food self-sufficiency through its productivity. The style of reform which is the process of seeking national identity drives a climate of freedom and development that is participatory in all fields. All of them have an impact on the development of policy objectives that affect their practice. The figure 2 is simply illustrated by the shift in values seen through changes in the objectives of land communalization policies.

Land communalization policies carried out in villages in Pituruh Subdistrict, Purworejo Regency are a series of policies composed of 2 (two) stages, namely the first stage of land communalization and the second stage of distribution of land use. The stage of land communalization aims to collect land and the right to cultivate it through farmers who fulfill certain conditions. The distribution phase of land use is the main mechanism in distributing welfare to farmers in need through the distribution of land cultivation rights based on village arrangements.

The regulation of agrarian resources is the focus of attention of Pancasila which is recognized by the community as a philosophy that contains the values of local Indonesian wisdom. Pancasila as a value system whose abstract existence as collective, personal, and religious social system has grown strongly rooted in the life of the Indonesian people and embedded in the customs, traditions and national culture ${ }^{14}$ (Sudjito, 2013). The pattern of thick communalistic and religious values in the regulation of literacy in Indonesia in Article 33 paragraph (3) of the 1945 Constitution becomes the legal umbrella for the regulation of literacy in Indonesia.

At the level under the 1945 Constitution is a decree of the People's Consultative Assembly (hereinafter referred to as TAP MPR) namely TAP MPR No. IX / MPR / 2001 concerning Agrarian Reform and Natural Resource Management. This TAP MPR shows that the regulation of natural resources is a central issue that is seriously addressed by the state. The problem of restructuring the possession, ownership, use and utilization of agrarian resources is important to be implemented in the framework of achieving the certainty and protection of law and justice and prosperity for all the people. Awareness of the diversity of types of land rights arising from adat law with the character of kinship and togetherness are regulated in Article 1 paragraph (2) and Article 6 concerning the social function of the land. Conversion of land rights becomes the state's mechanism to provide legal certainty to its holders. Article VII of UUPA's conversion provisions determines the right of pekulen/ sanggan/ gogolan according to their nature divided into 2 (two), permanent and non-permanent, which is subsequently converted into the right of ownership and usufructuary rights for the holder. The entire conversion process shall be requested on the right holder's initiative pursuant to Regulation of the Minister of Agriculture And Agrarian No. 2 of 1962 on concerning the Affirmation of Former Conversion and Registration of Indonesian Rights to Land. The regulation on this conversion also affirms the wish of the state to register all land parcels as stipulated in Government Regulation No. 24 of 1997 concerning Land Registry.

Land communalization as an option for land stewardship strategies has many benefits. Some of them are first, as instruments to achieve the welfare of all group members in their position as economic assets / capital. Secondly, as an effort to preserve agricultural land and prevent land conversion, thirdly as an adhesive instrument of social solidarity in groups, and fourth as an instrument of local political mobilization by village elites and the community. The first as an instrument to achieve group welfare is reflected in the basis of communal policy, namely the existence of similar interests and destiny. In the communalization of land, the joint land belongs to all members of the community, its realization can be referred to as belonging to a group/ property of the whole village or belonging to the institution that houses it, namely the village. The utilization can be used for productive agriculture or not. This is close to the social function of land rights as stipulated in Article 6 of the UUPA. Namely that ownership, control, land use must pay attention to and prioritize the public interest. This social function is manifested more decisively by joint ownership of land while avoiding the existence of individualization of land.

Second, the role of land communalization in the effort to protect agricultural land. Data from the Central Bureau of Statistics shows that during the period June 1998-June 2003, there was a conversion of 12.7 thousand ha of paddy land into non-agricultural land, while the conversion of non-lands to non-agricultural land reached almost 30 thousand ha. The data raises concerns, given the smaller size of agricultural land both paddy fields and non-paddy fields that would threaten national food security. As an agrarian country, agricultural land has an important position in ensuring the availability and fulfillment of food needs in our country. Food for the people of Indonesia in the form of rice and several other types of crops. Once the importance of the issue of food security, especially rice, there is even a jargon that rice can shake political stability. So that food security is important for political stability. Land communalization policies by the community will prevent the transfer of land ownership rights to other parties because it belongs to all members of the group. Restricting policies by community groups tend to be more effective in preventing land conversion while at the same time encouraging the use of productive agricultural land.

According to Pearce and Turner in Muhammad Igbal and 
Sumaryanto, there are three approaches that can be used in controlling the conversion of wetlands, namely (1) regulation (regulation); (2) acquisition and management (land acquisition and land management); and (3) incentive and charge (incentives and fines) ${ }^{15}$. This approach is more indicative of the role that must be performed by the government as a power organization. In the context of this government, it can be done not only on the top level government but also on the local / village government. In the Pituruh case, the roles and functions are carried out by the village as a place and organization that is trusted by the community in accommodating interests and regulating land use in the village.

Third, it is an adhesive instrument of social solidarity among group members. The lower the inequality of existing land tenure, the greater mutual prosperity between groups can be achieved which will lead to stronger solidarity in the group. Communalization as a farmers' strategy becomes a mechanism in realizing collectivity in groups through the unification of shared goals and aspirations among group members while being able to counteract negative external influences. Land communalization is an interesting phenomenon that in the development of globalization and economic politics that are increasingly liberal, the land will be more individualized, but through awareness of the common goals and needs of land in the land community, communalization actually occurs. The concept of collectivity in communalization of land also broke the general assumption that villages and villages were no longer astrongcommunity (gemeinschaft). They have been eroded by the money economy, individualism and materialism. The orientation and the main reason that the community is still trying to maintain the ongoing communal system of existing land is to maintain social balance. This is the main glue as well as being able to control the activities and behavior of community members in accordance with agreed norms. Appreciation for strong ties and solidarity in this group / community has been appreciated in Bangladesh. In Bangladesh by Grameen Bank, a model for providing collateral-free loans in the form of land or immovable capital was developed to overcome poverty and limited land as capital / collateral. The strength of solidarity and bonding in groups / communities can be an important social capital so that it is able to be converted to replace the position of collateral in the provision of credit by banks. This can be a lesson in the future, that the pattern of solidarity and communal ties held by farmers in the communal system of land is strong so that it gains trust beyond the value of land as an economic commodity that can be guaranteed.

Fourth, the role of the tradition of communicating speculative land and the distribution of its use as instruments in mass mobilization in the implementation of local politics. This tradition can be used as an instrument for the village government to mobilize the masses while influencing the community in supporting a village government policy. This is very potential and very much depends on the objectivity and leadership of a village head. Communalization of speculative land and the distribution of its use become a policy choice at the local level that meets the aspirations of justice for the local community.

\section{CONCLUSION}

Land communalization is an alternative policy model that is applied in order to regulate land ownership in a more organized manner with a strong collectivity bond in a community. Although explicitly the UUPA does not regulate it, the opportunity for formalization of communal rights is within the framework of the protection of adat law communities with their legal system which forms the basis of national agrarian law. Historical experience shows that land communalization is a policy choice taken by the state in order to carry out its politics both during colonialism and post-independence. Besides that, communalization as a form of community tradition and culture is the people's choice in managing their land. So that it can be said that the character of the land communal policy can be in the form of a national policy of the state which is the implementation of state politics (top down) and can also be a form of peasant movement in maintaining the integrity of the community (bottom up). Land communalization is a policy that aims to improve the welfare of farmers, prevent the conversion of agricultural land, and increase the solidarity of community members/ groups. The communalization model that develops at the local level, often requires a more rigorous supervision and regulatory mechanism to ensure there is no deviation and is used by certain parties. The synergy of the adat law model that develops in society with the ideals and formal laws of the state becomes an ideal alternative arrangement in the framework of mutual certainty and prosperity.

\section{REFERENCES}

1. Wiradi G. Reforma agraria, perjalanan yang belum berakhir. 1 ed. -, editor. Yogyakarta: Insist Press, KPA \& Pustaka Pelajar; 2000 September 2000. 247 p.

2. Aditjondro GJ. Aksi petani, represi militer, dan sosialisme marga: memperluas wacana permasalahan tanah di indonesia. In: Zakaria $\mathrm{R}$ and Lounela, editor. Berebut tanah: beberapa kajian berprespektif kampus dan kampung. Yogyakarta: Insist Press; 2002. p. 411.

3. Shohibbudin Muhammad and Ahmad Nashih Luthfi. Land reform lokal ala ngandagan: inovasi sistem tenurial adat di sebuah desa jawa, 1947-1965. 1 ed. Yogyakarta: STPN Press and Sajogyo Institute; 2010. 179 p.

4. Cahyati DD. Konflik agraria di urutsewu; pendekatan ekologi politik. 1 ed. Yogyakarta2014 Desember 2014. $227 \mathrm{p}$.

5. Puri Widhiana $\mathrm{H}$ and Sulastriyono. Tanah pekulen dalam struktur hukum agraria di jawa. Mimbar Hukum. 2016; 28:466-81.

6. Onghokham. Perubahan sosial di madiun selama abad xix: pajak dan pengaruhnya terhadap penguasaan tanah. In: Wiradi, Gunawaan and Tjondronegoro, Sediono MP. editor. Dua abad penguasaan tanah: pola penguasaan tanah pertanian di jawa dari masa ke masa. Jakarta: Yayasan Obor Indonesia; 2008. p. 521.

7. Suhartono. Apanage dan bekel. 1 ed. Yogyakarta: Tiara Wacana Yogya; 1991 April 1991. 220 p. 
Kristianto D. Land reform menata ruang-ruang komunal. 1 ed. Jakarta: Epistema; 2016 November 2016. 180 p.

8. Soekanto Soerjono and Soleman B. Taneko. Hukum adat indonesia. 5 ed. Jakarta: RajaGrafindo Persada; 2002 Juli 2002. $382 \mathrm{p}$.

9. Subekti. Hukum adat indonesia dalam yurisprudensi mahkamah agung. Bandung: Alumni; 1990.

10. Winarno B. Kebijakan publik: teori dan proses. 1 ed. Yogyakarta: Media Pressindo; 2007 2007. 320 p.

11. Aass, S. Relevansi teori makro chayanov untuk kasus pulau jawa. In: Wiradi, Gunawaan and Tjondronegoro, Sediono MP. editor. Dua abad penguasaan tanah: pola penguasaan tanah pertanian di jawa dari masa ke masa. Revised ed. Jakarta: Yayasan Obor Indonesia; 2008. p. 521.

12. Sudjito. Hukum dalam pelangi kehidupan. Yogyakarta: Tugujogja Pustaka; 2013. 205 p.

13. Sumaryanto and Muhammad Igbal. Strategi pengendalian alih fungsi lahan pertanian bertumpu pada partisipasi masyarakat. Analisis Kebijakan Pertanian. 2007;5 No. 2:167-82.

\section{AUTHOR PROFILE}

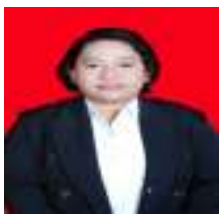

Widhiana Hestining Puri was born in Karanganyar, February 25, 1984. The author completed his undergraduate study at the Faculty of Law at Sebelas Maret University, Surakarta in 2006, and master of law at the same campus in 2008. Currently the author is pursuing her Ph.D education at the Faculty of Law, Gadjah Mada University. Since 2011, the author has joined the National Land Academy which is under the Ministry of Agrarian and Spatial Planning / National Land Agency. Besides become lecturer since 2013, the author is also involved in various research activities and community service at the center of research and community service PPPM in National Land Academy. Various studies in the field of law, especially agrarian and customary law have been carried out, some of which include tribe of "Anak Dalam Bathin 9" and Thousand Hectares of Asiatic Persada Palm Conflict, Contextuality of Affirmative Action in Land Policy in

Yogyakarta, Adat Village as a Form of Local Wisdom in The Land Sector in Bali, Land Management in Lembeh Island, Problems with Agrarian Institutional Sector in Indonesia, Pluralism of Agrarian Law in Indonesia, Pekulen Land in The Structure of Agrarian Law in Java and so on. The author corresponding email: widhianapuri@yahoo.com. 